\title{
ENRICHMENT OF EMPLOYABILITY SKILL AMONG MBA STUDENTS - A PATHWAY TO NEW INDIA
}

\author{
J. Santhi \\ Faculty of Management Studies, Sri Chandrasekharendra Saraswathi Viswa Mahavidyalaya, India
}

\begin{abstract}
India is well known for its well-structured educational system from the Vedic period. The number of institutions offering various professional courses including management program is increasing significantly. At the same time the challenges to be met by management graduates are also increasing at a faster pace. The various study and survey reports have brought in light that with the increase in quantity of $\mathrm{MBA}$ students there is a decrease in the average quality in terms of employability skill. The objective of this study is to explore the employability skill required by management graduates and the ways and means to enrich the same.
\end{abstract}

Keywords:

Employability Skill, Enrichment of Employability Skill

\section{INTRODUCTION}

The success of any industry whether it is a manufacturing sector, trading sector or service sector, is being determined by the efficient and effective management of the firm. Since every industry has to face tough competition from their domestic and foreign competitors, the firms nowadays prefer to avail the services of well-trained management graduates. This is the reason that Management education programs have gained its significant momentum over the last two decades. The numbers of institutions offering management education have increased in a tremendous manner. They have outstanding faculty members, demanding courses, and great employment opportunities. The Indian Institutes of Management are ranked so high in the world. The majority of the institutions are graduating MBA students with less employability skill. The expectation from the industry is high. There is a disparity between anticipation and actual employability skill among the MBA graduates. In order to bridge the gap between these two the employability skill has to be enriched. This study shed its light on the concept of employability skill and the need for its enrichment.

\subsection{STATEMENT OF THE PROBLEM}

The present scenario in India is the number of institutes offering management education has increased in India. At the same time the challenges to be met by management graduates also increasing at a faster pace. The various study and survey reports have brought in light that with the increase in quantity of MBA students there is a decrease in the average quality in terms of employability skill. The objective of this study is to explore the employability skill required by management graduates and the ways and means to enrich the same.

\subsection{OBJECTIVES OF THE STUDY}

- To gain the knowledge about the concept of employability skill
- To study the employability skill required for MBA Students

- To suggest the measures for enrichment of employability skill among MBA Students.

- Limitations of the Study

- The secondary data alone is used in this study. The study is of descriptive nature only.

\subsection{RESEARCH METHODOLOGY}

This paper is a conceptual study done on the basis of the literature survey of educational reports and articles. The secondary data collected from various journals, literature survey of educational reports and research papers have been used in this paper. Studies done in India and in other countries have been abridged in this paper.

\section{REVIEW OF LITERATURE}

Padmini [1] has identified that the inadequate skill set of workforce is the major stumbling block in the growth path of any sector. She has also identified the employability skills required by young graduates and assessed how there can be a value creation through effective knowledge management in terms of pedagogy, evaluation process and feedback mechanisms.

Nishad Nawaz and Krishna Reddy [2] have quoted that, enrichment of employability skill among management students is considered as an important task for all institutions offering management program. They have also stated that language competency; cognitive skills are to be strengthened among MBA graduates.

Sanket and Ravan [3] stated that employability skills are must for all the MBA students for getting the job. He has concluded that interpersonal skills, communication skill, decision making skill and leadership skills are to be developed among the students.

Padmakali and Kumar [4] presented the overview of recent trends about current employability skills of management students and skills needed by the industry. They have concluded that the Management curriculum needs to be revised at both Graduate and post graduate level. Curriculum should also link with Experimental and Action learning. The Faculty members should be given opportunity to enhance their knowledge related to Sustainable Development.

\section{EMPLOYABILITY SKILL}

Employability skills are the additional skills apart from the core skills and hard skills. The needs of employability skills differ from country to country and from sector to sector and from time to time. 
Table.1. Employability Skills

\begin{tabular}{|c|c|}
\hline $\begin{array}{l}\text { Employability } \\
\text { skill }\end{array}$ & Skill that relates to \\
\hline Communication & $\begin{array}{l}\text { The ability to express oneself clearly and } \\
\text { confidently through the spoken and written word. } \\
\text { Delivered in a clear manner, avoiding jargon and } \\
\text { pitched at a relevant level, so that it is received } \\
\text { and understood. }\end{array}$ \\
\hline Teamwork & $\begin{array}{l}\text { The ability to work effectively and confidently } \\
\text { within a group to achieve a common goal or task. } \\
\text { This will involve understanding role within the } \\
\text { team, and listening and supporting other team } \\
\text { members. }\end{array}$ \\
\hline $\begin{array}{l}\text { Planning, } \\
\text { Organising and } \\
\text { Time } \\
\text { Management }\end{array}$ & $\begin{array}{c}\text { The ability to manage self and/or others, } \\
\text { resources and time in order to complete goals } \\
\text { and tasks to schedule, whilst remaining in } \\
\text { control. }\end{array}$ \\
\hline $\begin{array}{l}\text { Analysing and } \\
\text { Problem Solving }\end{array}$ & $\begin{array}{l}\text { The ability to gather information in a systematic } \\
\text { way from a variety of sources in order to } \\
\text { establish facts; identifying possible cause and } \\
\text { drawing conclusions from a situation or problem. }\end{array}$ \\
\hline Initiative & $\begin{array}{l}\text { The ability to take responsibility and ownership } \\
\text { of own work, identify opportunities and be } \\
\text { proactive in putting forward own ideas. }\end{array}$ \\
\hline Self-Awareness & $\begin{array}{l}\text { The ability to identify one's own skills, } \\
\text { achievements, abilities, interests, values, } \\
\text { motivations and weaknesses. }\end{array}$ \\
\hline Flexibility & $\begin{array}{l}\text { The ability to adapt and change to different } \\
\text { situations and environments and to respond to } \\
\text { the needs, wishes and demands of others. }\end{array}$ \\
\hline $\begin{array}{l}\text { Numerical } \\
\text { Interpretation }\end{array}$ & $\begin{array}{l}\text { The ability to understand and be able to extract } \\
\text { appropriate meaning from numerical data and } \\
\text { express oneself effectively in quantitative terms. }\end{array}$ \\
\hline Action Planning & $\begin{array}{c}\text { Understanding the steps that need to be taken to } \\
\text { achieve specific targets and goals. }\end{array}$ \\
\hline $\begin{array}{l}\text { Personal Impact } \\
\text { and Confidence }\end{array}$ & $\begin{array}{l}\text { The ability to present a strong, professional } \\
\text { image which commands the respect of others. }\end{array}$ \\
\hline \multicolumn{2}{|r|}{ Further Skills Development } \\
\hline Leadership & $\begin{array}{l}\text { The ability to motivate, take responsibility and } \\
\text { lead other people, in order to achieve set goals } \\
\text { and objectives. }\end{array}$ \\
\hline Networking & $\begin{array}{l}\text { The ability to make and sustain contacts in order } \\
\text { to gather advice, information and potential } \\
\text { business and career development. Linked very } \\
\text { much to good communication skills. }\end{array}$ \\
\hline $\begin{array}{l}\text { Commercial } \\
\text { Awareness }\end{array}$ & $\begin{array}{l}\text { The ability to have an awareness of the business } \\
\text { issues that affect the industry, and to understand } \\
\text { the environment in which it operates in relation } \\
\text { to customers and competitors. }\end{array}$ \\
\hline Negotiating & $\begin{array}{l}\text { The ability to discuss and then reach a mutually } \\
\text { satisfactory agreement. This involves working } \\
\text { together with other people and building trust. }\end{array}$ \\
\hline $\begin{array}{l}\text { Computer } \\
\text { Literacy }\end{array}$ & $\begin{array}{l}\text { The ability to use a range of computer packages } \\
\text { and software including email, word-processing, }\end{array}$ \\
\hline
\end{tabular}

\begin{tabular}{|c|c|}
\hline & $\begin{array}{c}\text { databases, spreadsheets, and the Internet. These } \\
\text { are important skills that employers will expect. }\end{array}$ \\
\hline $\begin{array}{c}\text { Decision } \\
\text { Making }\end{array}$ & $\begin{array}{c}\text { The ability of choosing a course of action or the } \\
\text { best option by considering various paths open to } \\
\text { you, identifying the pros and cons and then } \\
\text { making a balanced judgement. }\end{array}$ \\
\hline Creativity & $\begin{array}{c}\text { The ability to generate new ideas and solutions } \\
\text { and to produce something new that has value to } \\
\text { others. }\end{array}$ \\
\hline Global Skills & $\begin{array}{c}\text { To understand and appreciate different cultures, } \\
\text { speak and understand different languages. }\end{array}$ \\
\hline
\end{tabular}

Source: University of Bolton

The Fig.1 shows the skill map required by MBA students as it is given by University of Kent

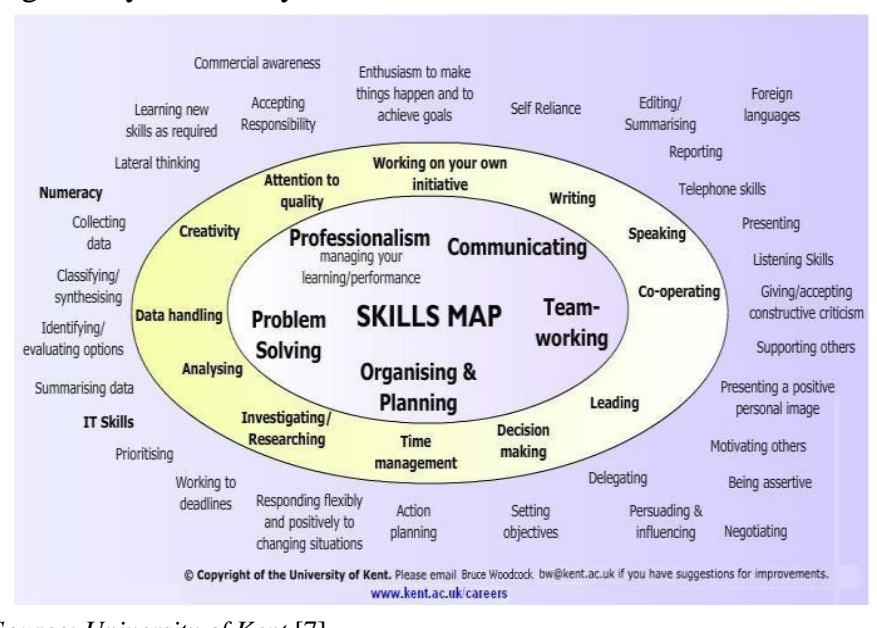

Source: University of Kent [7]

Fig.1. Employability Skills Map

\section{NEED FOR ENRICHMENT OF EMPLOYABILITY SKILL}

After a few years in the doldrums, the MBA is back as a course of choice. So this is the high time to reboot management education system in India. A joint effort is to be taken by government, industry and academia which in turn will help to enrich the employability skill among the students. On the following grounds the enrichment of personality can be justified:

- The world is competitive not only for students but also for institutions and so there is a lot of focus on quality education.

- The companies expect for people who are able to handle uncertainties, have a wider perspective and are leaders and not just managers.

- It is not just skills and knowledge that are important but companies are also looking at the right personality fit and emotional quotient of the individual.

- Unless and until the employability skills are enhanced, the worldwide recognition for MBA degree cannot be obtained [5].

- This has led the top flight management institutes to not only have a relook at their curriculum but also innovate on course delivery. 


\section{WAYS AND MEANS FOR ENRICHMENT OF EMPLOYABILITY SKILL AMONG MBA STUDENTS}

Many of the Industry Experts and Academicians have come up with their suggestions for improving employability among MBA students. Some of their valuable recommendations have been presented here under:

- Innovative Management Education thinkers: The traditional management education system offering specialisation in accounting, finance, marketing etc. alone will not help the students to take up their leadership role in various industries and in countries. So this is the time to introduce various unique specialisations based on the needs of the dynamic industrial environment. The need of the time is innovative management education thinkers who can frame such valuable curriculum.

- Integration with Industry: Integration with industry at the stage of framing the curricula will be more effective and target curriculum can suit to the needs of employers and thus employability gap can be reduced to a greater extent.

- Autumn Internship will be more effective than Summer Internship: Certain reputed institutions are offering autumn internship instead of summer internship. The students will start their internship three-four months after studying their specialisation subjects in the second year. The students will probably be better poised to apply their classroom knowledge in real world setting. Due to this, the project deliverables improve and the chances of companies giving a pre-placement offer are much higher.

- Good Research Facilities: The libraries well equipped with good number of books shall be made available for students and staff. These universities also shall give subscriptions to a number of the best academic databases that contain thousands of journals and papers from around the world. It's a great way for students to access the best and the latest in research to support their assignments with.

- Sound Admission Policy and Procedure: A sound and strict admission policy and procedure will help to avoid students without calibre graduating from the B Schools. It is generally being blamed that huge numbers and huge compromises in admissions leave the graduates unemployable. Higher education should be made easily available to the most worthy students and deserving candidates.

- Multinational Faculty: The practice adopted by the reputed institutions in the west is attracting the best brains from all over the world. This will help to bring a diversity and richness of thought to the field of education. These bright minds will lead to the quality of teaching at the highest level. This facility should be made available in our Indian institutes also.

\section{MIX OF TEACHING METHODS}

\subsubsection{Lectures:}

It is a strong philosophy that any course taught had to have a strong theoretical foundation by way of giving lectures. Delivering the lectures is a part of the holistic approach toward teaching. The lectures help to teach the concepts and disseminates the subject knowledge to the students.

\subsubsection{Case Study:}

Conferring the knowledge shall take place a part in class and a part by practice. One way of approaching the practice part is through the case method of teaching which involve letting the students in decision making scenarios. Under this method the role of faculty members will be more of facilitator of discussions rather than a giver of knowledge. Case studies, if properly used, can definitely stimulate a lot of thought.

\subsubsection{Others:}

Simulations, trading and real-life projects are the other modes of teaching management education. The students can be encouraged to use real time data for effective learning. An innovative pedagogical tool that takes students to real application of concepts into practice is the use of Live Company Projects. This projects can be undertaken during coursework. The live projects differ from other projects with respect to the fact that these are real work assigned by the company to the students. It will help the students to get a unique opportunity to apply the learned knowledge in the class in real life projects.

The Fig. 2 shows the average adoption of teaching methods followed by B-Schools in India. Depending upon dynamic market expectations the ratio of these methods can be reframed focusing more on case study and simulation as the case may be.

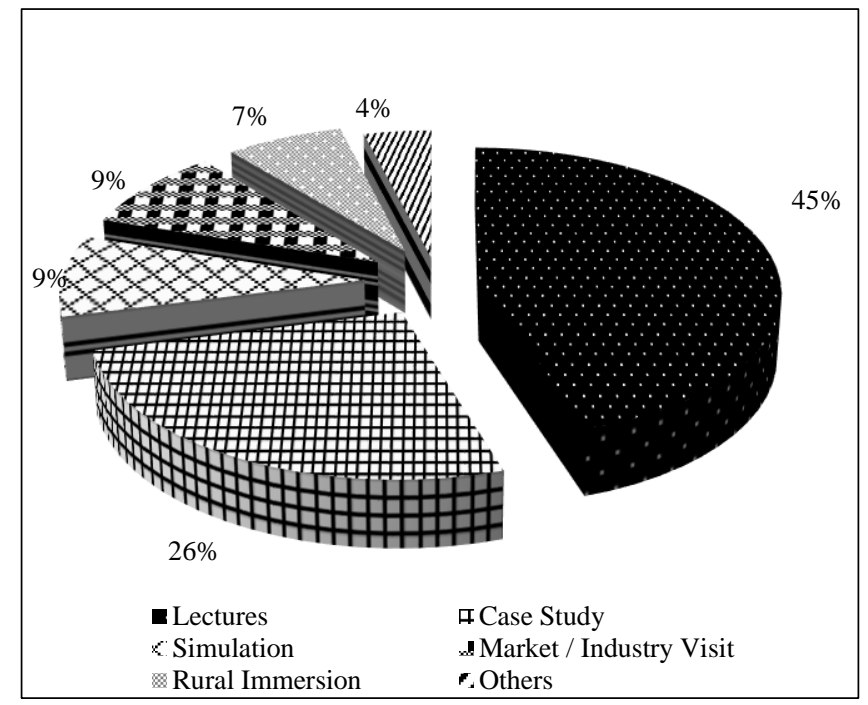

Source: Inform and Inspire [6]

Fig.2. Mix of Teaching Methods used by B-Schools in India 


\section{ETHICS IN MANAGEMENT COURSES}

It is often viewed that teaching ethics in management courses is an anachronism in today's world. But in practice it is felt that MBA graduates have not scored high marks in ethical front in their work place. The good values such as hard work, honesty, austerity, entrepreneurship etc., are very important to every MBA students. It is sure that the decent and hardworking people with high aspirations can make wonders in their work place. So it is essential to teach ethics to them.

\subsection{ROLE OF FACULTY IN INCULCATING GOOD QUALITIES AMONG MBA STUDENTS}

The teaching faculty are bound to inculcate the following qualities among the students:

- Motivating the students to learn from one's own experience

- Fostering self-introspection among the students

- Discipline

- Fostering probity

- Sense of Autonomy

Nurturing a sense of autonomy among the faculty is need of the time now. The faculty members shall be allowed to enjoy a sense of autonomy which will permit to go beyond their limits. Allowing them to work within a certain amount of freedom will help to tap their hidden teaching skills and other talents.

\subsection{INFRASTRUCTURE UPGRADATION}

A plan for continuous infrastructure up gradation is to be followed by every institution.

\section{CONCLUSION}

The demand is strong in India and worldwide for graduates who develop the potential to take on leadership roles in the international business arena. In future definitely there will be a dramatic change in the demand for MBA education if strategies are adopted for reducing the gap between the MBA Graduates and their employability skill. By reinventing the MBA pedagogy, the critical thinking and problem solving skills can be made as an identity of management students which in turn will serve as a pathway to new India. It is sure that India will excel in the field of talent management and knowledge management in the near future if the Government put its hands together with Higher Education Sector for providing quality education to the students. Thus, Graduating industry-ready competent MBAs can only be a winwin solution for the schools, students and for the corporate world.

\section{REFERENCES}

[1] I. Padmini, "Education Vs Employability-The need to Bridge the Skills Gap among the Engineering and Management Graduates in Andhra Pradesh", International Journal of Management and Business Studies, Vol. 2, No. 3, pp. 90-94, 2012

[2] Nawaz M. Nishad and Reddy B. Krishna, "Role of Employability Skills in Management Education: A Review", Zenith International Journal of Business Economics and Management Research, Vol. 3, No. 8, pp. 1-6, 2013.

[3] Sanket V. Ravan, "Employability Skills Need of an Hour for MBA Students", EPRA International Journal of Economic and Business Review, Vol. 4, No. 10, pp. 2016.

[4] Banerjee Padmakali and Patter Yogesh Kumar, "Perceived Competencies and Employability Level of Management Students", International Journal of Engineering and Management Sciences, Vol. 7, No. 1, pp. 41-45, 2016.

[5] India Skills Report 2017, Available at: https://wheebox.com/static/wheebox_pdf/india-skillsreport-2017.pdf

[6] The Hindu Business Line, "Inform and Inspire-A Special Handbook for MBA Aspirants", 2016

[7] The UK's European University, Available at: www.kent.ac.uk 